\title{
ANALYSIS OF SCIENCE LITERACY CAPABILITIES THROUGH DEVELOPMENT TEST OF SCIENTIFIC LITERACY SKILLS (TOSLS) INTEGRATED INTERNET OF THINGS (IOT) TECHNOLOGY
}

\author{
${ }^{1}$ Arfiati Ulfa Utami, ${ }^{2}$ Rachmaniah Mirza Hariastuti \\ Department of Mathematics Education, Faculty of Mathematics and Science, PGRI University \\ of Banyuwangi. Jl. Ikan Tongkol No. 01 Kertosari Banyuwangi, Indonesia. \\ Email: fieare@ymail.com
}

\begin{abstract}
Article Info
Article History

Received: 30 Juli 2019

Revised: 11 September 2019

Published: 30 September 2019

Keywords

Scientific literacy, Test of Scientific Literacy Skills (TOSLS), Internet of Things (IoT)

Abstract

Education has an important role in preparing students to have scientific literacy skills and to be able to solve problems in daily life in the face of modern life. In science learning science literacy is very important as the development of science and technology in this era of globalization, it is necessary to develop a Test of Scientific Literacy Skills (TOSLS) as a measure to determine the extent of students' literacy abilities. The Test of Scientific Literacy Skills (TOSLS) is packaged through internet technology, where students must be able to access the internet because the Test of Scientific Literacy Skills (TOSLS) is done online. This study aims to determine the scientific literacy skills of students through the development of the Test of Scientific Literacy Skills (TOSLS) integrated Internet of Things (IoT) technology. This study uses descriptive quantitative methods. The study sample was 35 students of class VII at Srono Banyuwangi 1 Public Middle School. The research instrument used was a test in the form of a Test of Scientific Literacy Skills (TOSLS) adapted from Gormally et al. This test is given to 20 students at Srono Banyuwangi 1 Public Middle School. The average results obtained using the TOSLS test in the category are sufficient (62.52).
\end{abstract}

Sitasi: Utami, Arfiati Ulfa. (2019). ANALYSIS OF SCIENCE LITERACY CAPABILITIES THROUGH DEVELOPMENT TEST OF SCIENTIFIC LITERACY SKILLS (TOSLS) INTEGRATED INTERNET OF THINGS (IoT) TECHNOLOGY. Vol. 1 No. 2: $1-5$

\section{PENDAHULUAN (INTRODUCTION)}

The development of science and technology in the era of industrial revolution 4.0 is very influential on life in society, especially in the world of education. Referring to the statement is that education is faced with increasingly difficult challenges. One of the challenges is that education should be able to produce human resources that have full ability to face various challenges in life (Yuliati: 2017). According to Supriyanto dalam (Kompasiana: 2019), talking about the reality in the world of education in Indonesia, that it turns out that the coveted hopes are not in accordance with the reality of our Indonesian education goals. The quality of education in Indonesia at this time is very low. This is supported by United Nations Educational Scientific and Organizations (UNESCO) research on quality in all developing countries, Indonesia is ranked 10th out of 14 countries. The education era 4.0 is an era where a teacher gets a tough challenge and must be faced. In science learning in school science literacy is very important as the development of science and technology in this era of globalization. Scientific literacy ability is a fundamental thing that must be possessed by students in facing the global era to be able to fulfill life's needs in various situations. Science literacy is the ability to understand science, communicate science, and apply science skills to solve problems (Yuliati: 
2017). The researcher has developed a scientific literacy evaluation instrument that has been tested for validity and reliability, namely the Test of Scientific Literacy Skills (TOSLS), a Test of Scientific Literacy Skills (TOSLS) is needed to measure the literacy abilities of students.

The Test of Scientific Literacy Skills (TOSLS) indicators includes (1) identifying the appropriate scientific argument, (2) using an effective literature search, (3) evaluating the use of scientific information, (4) understanding the research design elements and how they affect scientific discovery, (5) making graphs that can represent data, (6) reading and interpreting data, (7) solving problems using quantitative capabilities including probability statistics, (8) understanding and being able to interpret basic statistics, (9) presenting conclusions, predictions based on quantitative data (Gormally: 2012). The Test of Scientific Literacy Skills (TOSLS) is packaged through the Internet of Things (IoT) technology, where students must be able to access the internet because the Test of Scientific Literacy Skills (TOSLS) is done online. The development of the Test of Scientific Literacy Skills (TOSLS) through the Internet of Things (IoT) is expected effectively for measuring scientific literacy skills by utilizing the digital world for the millennial generation of Indonesia.

\section{METODE (RESEARCH METHOD)}

The type of research used in this study is descriptive research that aims to identify students' literacy skills in the measurement material. The research subjects were grade VII students at Srono Banyuwangi 1 Public Middle School. The instrument used was a scientific literacy ability test tool developed by the author with reference to the indicators contained in the development of the TOSLS test by Gormally et al (2012).

Table 1. Score Interpretation Criteria (Arikunto: 2013)

\begin{tabular}{|c|c|}
\hline Criteria Score Interval & Criteria \\
\hline $80-100$ & Very good \\
\hline $66-79$ & Good \\
\hline $56-65$ & Enough \\
\hline $40-55$ & Less \\
\hline $30-39$ & Very Less \\
\hline
\end{tabular}

\section{HASIL DAN PEMBAHASAN (RESULTS AND DISCUSSION)}

Based on the results of the study obtained data on scientific literacy skills. Science literacy is the ability to use scientific knowledge, identify questions and draw conclusions based on evidence and make decisions regarding nature and changes made to nature through human activities. Literacy skills will be evaluated based on the development of the Test of Scientific Literacy Skills (TOSLS) below:

Table 2. Indicators of TOSLS

\begin{tabular}{|c|c|c|}
\hline & Indicator & Sub Indicators \\
\hline I & $\begin{array}{l}\text { Understand inquiry methods that lead } \\
\text { to scientific knowledge }\end{array}$ & $\begin{array}{l}\text { 1. Identify the appropriate scientific } \\
\text { argument } \\
\text { 2. Using effective literature search } \\
\text { 3. Evaluation in using scientific } \\
\text { information }\end{array}$ \\
\hline
\end{tabular}




\begin{tabular}{|c|l|l|}
\hline & \multicolumn{1}{|c|}{ Indicator } & \multicolumn{1}{c|}{ Sub Indicators } \\
\hline II & $\begin{array}{l}\text { Organizing, analyzing, and } \\
\text { interpreting quantitative data and } \\
\text { scientific information }\end{array}$ & $\begin{array}{l}\text { 4. Understanding the elements of research } \\
\text { design and how it impacts on scientific } \\
\text { discovery }\end{array}$ \\
\hline & $\begin{array}{l}\text { 1. Creating graphs that can represent data } \\
\text { 2. Read and interpret data } \\
\text { 3. Problem solving using quantitative } \\
\text { capabilities including probability } \\
\text { statistics a }\end{array}$ \\
$\begin{array}{l}\text { 4nderstanding and being able to } \\
\text { interpret basic statistics } \\
\text { Presenting conclusions, predictions } \\
\text { based on quantitative data }\end{array}$ \\
\hline
\end{tabular}

Table 3. Results of Science Literacy Based on TOSLS Indicators

\begin{tabular}{|l|c|c|}
\hline \multicolumn{1}{|c|}{ Indicator } & Percentage & Category \\
\hline Identifying the exact scientific argument & 85,43 & Very good \\
\hline Using effective literature searches & 48,76 & Less \\
\hline Evaluation in using scientific information & 75,91 & Good \\
\hline $\begin{array}{l}\text { Understand the elements of research design and how the } \\
\text { impact on scientific discovery }\end{array}$ & 54,98 & enough \\
\hline Make graphs that can represent data & 30,65 & Very less \\
\hline Read and interpret data & 68,99 & Good \\
\hline $\begin{array}{l}\text { Problem solving using quantitative capabilities including } \\
\text { probability statistics }\end{array}$ & 88,71 & Very good \\
\hline Understand and be able to interpret basic statistics & 48,33 & Less \\
\hline $\begin{array}{l}\text { Presenting conclusions, predictions based on quantitative } \\
\text { data }\end{array}$ & 60,94 & Enough \\
\hline
\end{tabular}

The average value of scientific literacy skills obtained in this study is $45.80 \%$ in the medium category. Based on the results of tests of scientific literacy skills the highest average was obtained at 88.71 on the indicators of problem solving skills using quantitative capabilities including probability statistics, while the lowest average was 30.65 in the graphical indicator that could represent data.

According to PISA (Emilianur: 2010) defines scientific literacy as the capacity to use scientific knowledge and abilities, identify questions and draw conclusions based on existing evidence and data in order to understand and assist researchers to make decisions about the natural world and interactions human with nature. Science literacy is defined as the ability to use scientific knowledge, identify questions and draw conclusions based on evidence in order to understand and make decisions regarding nature and changes made to nature through human activities. PISA sets out three major dimensions of science in its measurement, namely science processes, science content and science application contexts. Science processes refer to the mental processes involved when answering a question or solving a problem, such as identifying and interpreting evidence and explaining conclusions, content science refers to the key concepts needed to understand natural phenomena and changes made to nature through human activities. In this regard PISA does not specifically limit the scope of science content only to 
knowledge that is a school science curriculum material, but also includes knowledge that can be obtained through other sources.

According to PISA which was cited (Odja: 2014), scientific literacy evaluations carried out gave attention to the cognitive and affective aspects of students. Cognitive aspects include student knowledge and its capacity to use effectively and involve cognitive processes that are characteristic of science in the personal, social and global fields. Affective aspects relate to problems that can be solved by scientific knowledge and form students who are able to make decisions now and in the future. PISA specifies three aspects of the following scientific components / processes in scientific literacy assessment, namely identifying scientific questions, explaining phenomena scientifically and using scientific evidence. In the last few years the learning assessment paradigm has begun to change from all paper-based ones to computer-based ones (Kompasiana, 2019). The development of digital technology that has penetrated all aspects of life, including the aspect of education. In science learning there have been many development of learning devices that use digital media, but there have not been many uses for the evaluation process (Syarifuddin: 2013). Evaluation of scientific literacy skills applied in the Test of Scientific Literacy Skills (TOSLS) integrated Internet of Things (IoT) is effectively carried out. It is proven that the use of the Test of Scientific Literacy Skills (TOSLS) integrated with Internet of Things (IoT) as an evaluation instrument makes it easier for teachers to process grades, because correction can be done directly as well as for students to immediately get a feed back.

The average scientific literacy ability obtained through the Test of Scientific Literacy Skills (TOSLS) integrated Internet of Things (IoT) is $45.80 \%$ with the medium category. In this case the indicator (1) identifies the exact scientific argument that is 85.43 in the excellent category. This is proven in large part that students have been able to identify arguments appropriately about the material of measurement, the use of types of measuring instruments in everyday life. (2) Using effective literature searches that is 48.76 in the less category because there are still some students who are confused about effective literature searches, so feedback must be given to students (3) Evaluation using science information is 75.91 in the good category because students are able to answer about the basic concepts of measurement. (4) Understanding the elements of research design and how the impact on scientific discovery is 54.98 in sufficient category. There are still some students who do not understand the research design and how it impacts scientific research on science subjects. Then feedback must be held and provide an explanation about research design in science subjects. (5) Creating a graph that can represent data is 30.65 in a very less category. Students are still having difficulty in making graphs to represent the research data, need to be given feedback and given more detailed explanations about making graphs of research results. (6) Reading and interpreting data is 68.99 in good categories. In some questions students are able to read the volume measurement data on the measurement material. (7) Problem solving using quantitative capabilities including probability statistics of 88.71 in very good categories. All students have been able to work on questions about solving problems in everyday life on measurement material. (8) Understanding and being able to interpret basic statistics is 48.33 in the less category. Students are not accustomed to using statistics in working on the problem, so the student feels difficulties and needs feedback for students. (9) Presenting conclusions, predictions based on quantitative data, namely 60.94 with sufficient categories. Some have been able to provide conclusions and predictions on several events in everyday life. 


\section{KESIMPULAN (CONCLUSION)}

Based on the results of the research that has been done, it can be concluded that the average scientific literacy ability is 45.80 in the medium category. Achieving scientific literacy skills through development that is applied in the Test of Scientific Literacy Skills (TOSLS) integrated Internet of Things (IoT) is effectively carried out. It is proven that the use of the Test of Scientific Literacy Skills (TOSLS) integrated with Internet of Things (IoT) as an evaluation instrument makes it easier for teachers to process grades, because correction can be done directly as well as for students to immediately get a feed back.

\section{SARAN (SUGGESTIONS)}

Suggestion for researchers especially in the field of education in evaluating literacy skills can develop different measuring instruments

\section{UCAPAN TERIMA KASIH (ACKNOWLEDGMENT)}

Special acknowledgments for Lembaga Layanan Pendidikan Tinggi (LLDIKTI) Wilayah VII Surabaya, Chairman LPPM PGRI University of Banyuwangi has contributed to the research.

\section{DAFTAR PUSTAKA (REFERENCES)}

Arikunto, S. 2013. Dasar-dasar Evaluasi Pendidikan Edisi Kedua. Jakarta: Bumi Aksara Azhar Syarifuddin. 2013. Pengembangan Instrumen Bloom Digital Assessment (BDA) Pada Materi Pokok Lingkaran Di Kelas VIII. Jurnal MATHEdunesa. Vol 2, No 2 (2013)

Gormally, Cara et al. (2012). Developing a Tests of Scientific Literacy Skills (TOSLS); Measuring Undergraduates Evaluation of Scientific Information and Argument. CBELife Science Education, 11:364-377

Supriyanto, Edi. 2019. Evaluasi dan Penilaian Pembelajaran Berbasis ICT. Kompasiana. Diakses melalui https://www.kompasiana.com/edisupriyanto8197/5cd20f1495760e6c0355d9e4/evalua si-dan-penilaian-pembelajaran-berbasis-ict

Suryawati, D. 2019. Persaingan Dunia Pendidikan era Revolusi Industri 4.0. Kompasiana. Diakses melalui https://www.kompasiana.com/dessysuryawati7807/5ce21e2a733c435273393547/pendidikanindonesia-bersaing-di-era-revolusi-industri-4-0-mampukah\#

Yuliati, Yuyu. 2017. Literasi Sains Dalam Pembelajaran IPA. Jurnal Cakrawala Pendas. Vol 3, No 2 (2017) 